\title{
A newly constructed and validated isoflavone database for the assessment of total genistein and daidzein intake
}

\author{
Margaret R. Ritchie ${ }^{1}$, John H. Cummings ${ }^{2}$, Michael S. Morton ${ }^{3}$, C. Michael Steel ${ }^{1}$, Caroline Bolton-Smith ${ }^{4}$ \\ and Andrew C. Riches ${ }^{1}$ \\ ${ }^{1}$ Bute Medical School, University of St Andrews, St Andrews, Fife KY16 9TS, UK \\ ${ }^{2}$ Division of Neuroscience and Pharmacology, Ninewells Hospital, Dundee, UK \\ ${ }^{3}$ Department of Medical Biochemistry, University of Cardiff College of Medicine, Cardiff, UK \\ ${ }^{4} 14$ Six Mile Bottom Road, West Wratting, Cambridge, UK
}

(Received 23 January 2005 - Revised 16 June 2005 - Accepted 16 August 2005)

\begin{abstract}
The principal phyto-oestrogens (PO) in food are isoflavones, lignans, coumestans and prenylated flavonoids, with isoflavones and lignans being the most commonly found in UK diets. Until recently obtaining accurate data on the PO content of foods was hampered by lack of suitable analytical methods and validation techniques. Furthermore, although PO data exist for some foods, these foods may not be available in the UK. The aim of the present study was to construct a new, comprehensive isoflavone (total genistein + daidzein) database. Using data, mainly from recent GC-MS analysis, for approximately 300 foods available in the UK, and extensive recipe calculations, a new database was constructed containing approximately 6000 foods allocated an isoflavone value. By analysing $7 \mathrm{~d}$ weighed food diaries, the database was subsequently used to estimate isoflavone intake in two groups of healthy volunteers, omnivores $(n 9)$ and vegetarians $(n 10)$. Mean isoflavone intake in the vegetarian and omnivorous group was 7.4 (SEM 3.05) and 1.2 (SEM 0.43) mg/d, respectively. Mean intake for the total group was 4.5 (SEM 1.89) mg/d. Main food sources of isoflavones for the vegetarian group were soya milk (plain), meat-substitute foods containing textured vegetable protein and soya protein isolate, soya mince, wholemeal bread and rolls, white bread and rolls, croissants and pitta breads, beans, raisins and soya sauce. Main food sources of isoflavones for the omnivorous group were soya yogurts, wholemeal bread and rolls, white bread and rolls, garlic bread, nan bread and brown bread, sultanas and scones.
\end{abstract}

Isoflavone database: Recipe calculations: Dietary intake

There is increasing interest in phytochemicals and their role in disease prevention. Phytochemicals include dietary phyto-oestrogens (PO) such as the isoflavones genistein and daidzein, present in fruits, nuts, peas and beans, lentils, chickpeas and soya (Setchell et al. 1987; Franke et al. 1995; Mazur et al. 1996; Reinli \& Block, 1996; Liggins et al. 1998, 2000a,b, 2002; Mazur \& Adlercreutz, 1998), lignans, which are present in cereals, beans, peas, tea (black and green), wine and strawberries (Thompson et al. 1991; Obermeyer et al. 1995; Adlercreutz \& Mazur, 1997; Nesbitt \& Thompson, 1997; Bingham et al. 1998; Mazur \& Adlercreutz, 1998, Mazur et al. 1998a,b, 2000; Glitso et al. 2000) and prenylated flavones found in hops (Rong et al. 2000).

Soya is recognised as the major dietary source of PO (Bingham et al. 1998; Mazur \& Adlercreutz, 1998, 2000; United States Department of Agriculture \& Agricultural Research Service, 2004) and soya-based products have been shown to contain significant quantities of the isoflavones genistein and daidzein (Murphy et al. 1999; Pillow et al. 1999). Since genistein and daidzein are the most prevalent dietary isoflavones, values for their amounts in foods were used in the construction of the new isoflavone database.

There are a number of factors which can affect the isoflavone concentration in plants such as plant species and strain, crop year and geographical location (Franke et al. 1995). Processing can also affect isoflavone concentrations (Wang et al. 1990).

Although several databases have been constructed containing the isoflavone content of foods (Pillow et al. 1999; HornRoss et al. 2000; United States Department of Agriculture \& Agricultural Research Service, 2004; Vegetal Estrogens in Nutrition and Skeleton (VENUS), 2005), there is no current isoflavone database comprehensive enough to be used in epidemiological studies in the UK which assess the dietary impact of isoflavones on the health of a population.

The new isoflavone database has been constructed using a combination of techniques including results from previous analyses (Knight et al. 1998; Mazur \& Adlercreutz 1998; Pillow et al. 1999; Horn-Ross et al. 2000), more recent analyses (Liggins et al. 1998, 2000a,b, 2002), recipe calculations and 
nutrient information obtained from several major supermarket chains in Tayside, UK, including Sainsburys, Asda, Tesco, Morrisons, Iceland and Farmfoods. Foods from supermarkets were sampled and ingredient lists and variations in ingredient lists were checked by telephone calls to supermarket head offices and stores in other areas within the UK. Nutrient information was also obtained from UK food manufacturers relating to over 1600 bakery and frozen products.

\section{Methods}

Initially the sum of genistein and daidzein values were allocated to a range of foods on the database, many of which were identified from over 1000 food diaries, $24 \mathrm{~h}$ dietary recalls and food-frequency questionnaires obtained during several studies over a 4-year period (Ritchie et al. 2004a,b,c; Heald et al. 2005).

A database should be constructed with, as far as possible, one method of analysis being used throughout (Ziegler, 2001) and the analysis should be recent, reliable and sensitive (Ovaskainen et al. 1996; Ziegler, 2001). For these reasons, values of genistein and daidzein used in construction of the UK isoflavone database were mainly obtained from recent analyses carried out by Liggins et al. (1998, 2000a,b, 2002) using GC-MS. Although some HPLC values for the isoflavone content of foods were used in the database construction, HPLC analysis of foods was not considered sensitive, reliable and accurate enough to be used with great confidence. For example, in Table 1, the results for analyses performed by researchers (Adlercreutz \& Mazur, 1997; Mazur \& Adlercreutz, 1998; Liggins et al. 2002) largely concur; however, those for green split peas and mung bean sprouts differ considerably from values published by Franke et al. (1995). The database also included brand names and recipe dishes (Ovaskainen et al. 1996).

\section{Construction of new isoflavone database}

Since genistein and daidzein are the principal isoflavones in the diet (Pillow et al. 1999), comprising more than $90 \%$ of the intake of oestrogenic isoflavones, the sum of levels of these compounds in foods was allocated to corresponding foods in the database. In order to distinguish values to be used for the database construction, all the isoflavone data gathered from research papers underwent quality assurance (Ovaskainen et al. 1996; Ziegler, 2001) involving a number of steps.

For foods analysed, did the author specify the following?

- type of food and country of origin;

- McCance \& Widdowson (M\&W) code;

- if food was raw or cooked;

- if the results were for dry weight or wet weight (as is);

- the type of internal standard used;

- method of analysis (including CV quoted, multiple sample analyses for accuracy, adequate level of detection).

It was essential that all these criteria were fulfilled in order for results to be considered for inclusion in the database (exceptions were 'new user foods' without M\&W codes).

Table 2 is an example of the quality assurance carried out.

Comparison of genistein and daidzein concentrations in cereals by different methods of analysis was also performed and values are presented in Table 3.

\section{Recipe calculations}

All isoflavone values quoted represent the sum of genistein + daidzein and are in $\mu \mathrm{g}$ per $100 \mathrm{~g}$ for wet weight.

The same mathematical formula was used for calculating isoflavone content of bakery products involving the ratio of protein content of the required bakery product. For example, brown rolls crusty (A)/protein content of the same bread

Table 1. Comparison of genistein and daidzein values obtained by different studies for selected vegetables (adapted from Liggins et al. 2000b)

\begin{tabular}{|c|c|c|c|}
\hline Food & Study & Daidzein ( $\mu$ g per $100 \mathrm{~g}$ ) & Genistein ( $\mu$ g per $100 \mathrm{~g})$ \\
\hline Soyabeans boiled* & Liggins et al. (2002) & 15000 & 32000 \\
\hline Soyabeans boiled* & Mazur et al. (1998a) & 20000 & 32000 \\
\hline Miso* & Liggins et al. (2002) & 59000 & 67000 \\
\hline Miso* & Adlercreutz \& Mazur (1997) & 19000 & 31000 \\
\hline Bean sprouts (mung)* & Liggins et al. (2002) & 39000 & 6800 \\
\hline Bean sprouts (mung) $†$ & Adlercreutz \& Mazur (1997) & 800 & 1900 \\
\hline Bean sprouts (mung) $†$ & Franke et al. (1995) & nd & nd \\
\hline Broad beans* & Liggins et al. (2002) & 7 & 6 \\
\hline Broad beans $†$ & Mazur \& Adlercreutz (1998) & 24 & $\operatorname{tr}$ \\
\hline Broccoli, calabrese* & Liggins et al. (2002) & nd & nd \\
\hline Broccoli, calabrese $†$ & Adlercreutz \& Mazur (1997) & 5 & 7 \\
\hline Carrots* & Liggins et al. (2002) & nd & nd \\
\hline Carrots $†$ & Adlercreutz \& Mazur (1997) & 2 & 2 \\
\hline Cranberry* & Liggins et al. (2002) & 5 & 21 \\
\hline Cranberry† & Adlercreutz \& Mazur (1997) & 0 & 0 \\
\hline Green split peas* & Liggins et al. (2002) & 13 & 35 \\
\hline Green split peas $†$ & Mazur et al. (1998a) & 8 & 0 \\
\hline Green split peas & Franke et al. (1995) & 7300 & nd \\
\hline Mushrooms* & Liggins et al. (2002) & 1 & 21 \\
\hline Mushrooms† & Adlercreutz \& Mazur (1997) & 20 & 12 \\
\hline
\end{tabular}

$\mathrm{nd}$, not detected; $\mathrm{tr}$, isoflavone identified but could not be quantified.

${ }^{*}$ Concentrations expressed on a wet-weight basis.

† Concentrations expressed on a dry-weight basis. 


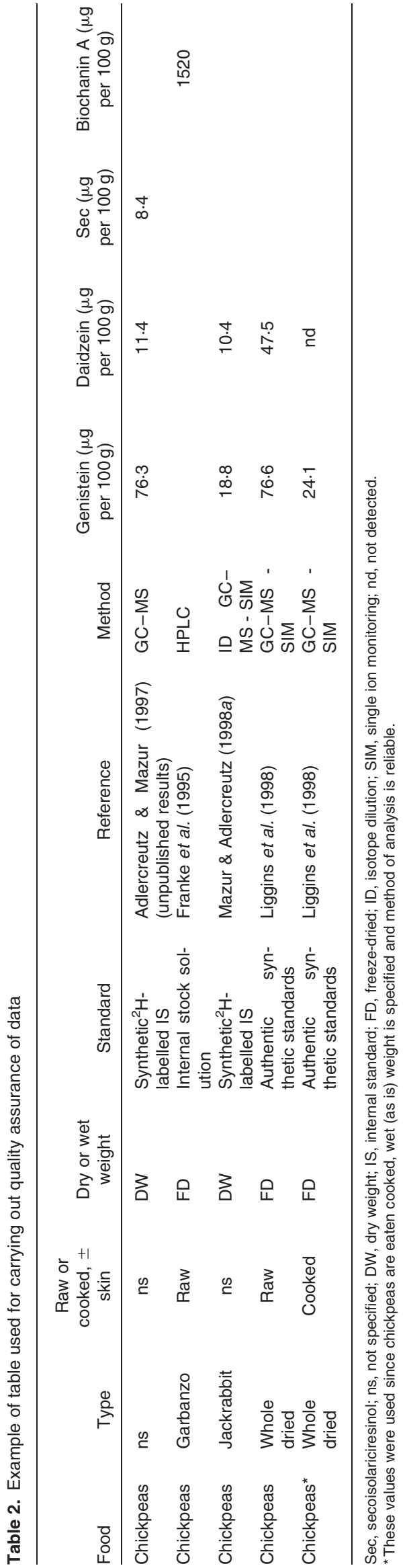

type, for example, brown bread (B) $\times$ isoflavone concentration of bread type, as measured by Liggins et al. $(2000 a, b, 2002)$. It was assumed that isoflavone content in bakery products is proportional to protein content. See Table 4 and Appendix 1.

Calculations (Appendix 1) for estimation of isoflavone content of composite dishes were carried out in a similar manner to those used for beef sausages (Table 5), fish pie and carrot and bean salad dishes.

Three brand-name soya milks were analysed for total genistein + daidzein content (by M. S. M.) using GC-MS. These foods were entered onto the database as 'new user' foods (see Table 6).

The isoflavone content of sweetened soya milk (M\&W food code $(\mathrm{FC}) 12043)=(\mathrm{A}+\mathrm{B}) / 2 \mu \mathrm{g}$ per $100 \mathrm{~g}$;

So, the estimated isoflavone content of sweetened soya milk $=8155 \mu \mathrm{g}$ per $100 \mathrm{~g}$.

The isoflavone content of plain soya milk was calculated by averaging isoflavone values for soya milk (published and unpublished values). The values used are listed in Table 7.

Isoflavone (genistein + daidzein) estimated values for foods

These were obtained in two ways:

- by calculation using a recipe;

- by comparison with isoflavone values for similar foods which had been analysed.

For example, the isoflavone content of raisins (M\&W FC $14242)=183.6 \mu \mathrm{g}$ per $100 \mathrm{~g}(\mathrm{~A})$;

The isoflavone content of currants (M\&W FC $14074)=224.5 \mu \mathrm{g}$ per $100 \mathrm{~g}(\mathrm{~B})$;

So, the estimated isoflavone content of sultanas $=$ content $(\mathrm{A}+\mathrm{B}) / 2=204 \cdot 1 \mu \mathrm{g}$ per $100 \mathrm{~g}$;

The isoflavone content of database addition $(\mathrm{M} \& \mathrm{~W} F C$ $14263)=204 \cdot 1 \mu \mathrm{g}$ per $100 \mathrm{~g}$.

Further examples of estimated isoflavone values and corresponding foods used in allocation of isoflavone levels are listed in Table 8.

\section{Isoflavone (genistein + daidzein) for 'second generation' soya-containing foods}

Several foods containing soya extract which were consumed by volunteers did not appear on the database (i.e. no $\mathrm{M} \& \mathrm{~W}$ FC) and subsequently had to be added. Furthermore, there was no reference to their isoflavone content in the literature. Isoflavone content of the food item was estimated using nutrient information present on food wrappers detailing the percentage composition. A 'new user food' code was also designated. An example of this is given in Appendix 2.

\section{Assessment of dietary isoflavone intake using the database:} rationale

Once constructed, it was necessary to test the database. The validity of the database was tested using the method of duplicate diet analysis (Ritchie et al. 2004a). The accuracy of the database was tested by using it to assess dietary isoflavone intake in healthy volunteers consuming a range of intakes (vegetarians and omnivores), i.e. two groups, with different anticipated isoflavone intakes. 
Table 3. Comparison of genistein and daidzein concentrations $(\mu \mathrm{g}$ per $100 \mathrm{~g}$ ) obtained by different studies for selected cereals (adapted from Liggins et al. 2002)

\begin{tabular}{llcc}
\hline Food & \multicolumn{1}{c}{ Study } & Daidzein $(\mu \mathrm{g}$ per 100 g) & Genistein $(\mu \mathrm{g}$ per 100 g) \\
\hline Bread, white & Liggins et al. (2002) & 135.6 & 157.2 \\
Bread, white & Horn-Ross et al. (2000) & 606.0 & \\
Bread, wholegrain & Liggins et al. (2002) & 373.1 & 456.7 \\
Bread, wholegrain & Horn-Ross et al. (2000) & 155.8 & 141.8 \\
Oatmeal & Liggins et al. (2002) & nd & nd \\
Oatmeal & Horn-Ross et al. (2000) & 0 or trace & 0 or trace \\
Oatmeal & Adlercreutz \& Mazur (1997) & 3.5 & 6.0 \\
\hline
\end{tabular}

nd, not detected

Table 4. Isoflavone (genistein (G) plus daidzein (D)) values for other bakery products

\begin{tabular}{|c|c|c|c|}
\hline Food & M\&W food code & Protein (\%) & Total $\mathrm{G}+\mathrm{D}$ content $(\mu \mathrm{g}$ per100 $\mathrm{g})$ \\
\hline White rolls, soft & 11124 & $9 \cdot 2$ & $320 \cdot 7$ \\
\hline Brown rolls, crusty & 11118 & $10 \cdot 3$ & $635 \cdot 7$ \\
\hline Brown rolls, soft & 11119 & $10 \cdot 0$ & $624 \cdot 5$ \\
\hline Wholemeal, rolls & 11125 & $9 \cdot 0$ & $811 \cdot 8$ \\
\hline Croissants & 11120 & $8 \cdot 3$ & $289 \cdot 3$ \\
\hline Chapatis made with fat & $\mathrm{R} 11074$ & $8 \cdot 1$ & $282 \cdot 3$ \\
\hline Chapatis made minus fat & 46 & $7 \cdot 3$ & 254.5 \\
\hline Nan bread & 11086 & 8.9 & $310 \cdot 2$ \\
\hline Pitta bread & 11090 & $9 \cdot 2$ & $310 \cdot 7$ \\
\hline Rye bread* & 48 & - & 33 \\
\hline
\end{tabular}

M\&W, McCance \& Widdowson.

${ }^{*}$ Assumes isoflavone value same as that for granary bread (Liggins et al. 2002).

Table 5. Genistein (G) plus daidzein (D) values for other meat products

\begin{tabular}{|c|c|c|c|c|}
\hline Food & M\&W food code & TVP (\%) & Potato (\%) & Total $\mathrm{G}+\mathrm{D}$ content $(\mu \mathrm{g}$ per $100 \mathrm{~g}$ \\
\hline Beef sausages, 'Premium' & 19095 & 0.85 & & 580 \\
\hline Frankfurters & 19100 & 0.99 & & 676 \\
\hline Beefburgers, fried & 19029 & 0.75 & & 512 \\
\hline Beefburgers, low-fat & 19037 & 0.75 & & 512 \\
\hline Bridie or scotch pie & 19053 & 0.98 & & $253^{*}$ \\
\hline Cornish pastie & 19056 & 0.98 & & $253^{*}$ \\
\hline Fishcakes & 16281 & & $7 \cdot 2$ & 0.2 \\
\hline
\end{tabular}

M\&W, McCance \& Widdowson; TVP, textured vegetable protein.

${ }^{*}$ Assume $G+D$ are found in meat only, which is $40 \%$ of food.

Isoflavone intake in a group of healthy volunteers consuming a vegetarian or an omnivorous diet

The aim of the present study was to determine usual isoflavone intake in healthy vegetarians and omnivores living in the Dundee area using a $7 \mathrm{~d}$ weighed food diary.
Study design and methods

Nineteen healthy volunteers (age range 19-76 years), seventeen female and two male were recruited by advertisement (poster) in Ninewells Hospital and Dundee University. The group consisted of nine omnivores, eight females, one male,

Table 6. Phyto-oestrogen (genistein and daidzein) values for branded soya milks (MS Morton, unpublished results)*

\begin{tabular}{lccc}
\hline Brands of soya milk & Daidzein $(\mu \mathrm{g}$ per $100 \mathrm{~g})$ & Genistein $(\mu \mathrm{g}$ per $100 \mathrm{~g})$ & New user \\
\hline 'So good' $(\mathrm{A})$ & 1530 & 4270 & MR19 \\
Tesco sweetened soya milk (B) & 2720 & 7790 & MR17 \\
Tesco unsweetened soya milk (C) & 5040 & 12800 & MR18 \\
\hline
\end{tabular}

${ }^{*}$ Analysis was carried out according to the method of Pumford et al. (2002) and Ritchie et al. (2004a). 
Table 7. Isoflavone (total genistein (G) plus daidzein (D)) values used for estimating the content of plain soya milk*

\begin{tabular}{lc}
\hline Author & $\mathrm{G}+\mathrm{D}$ content $(\mu \mathrm{g}$ per $100 \mathrm{~g})$ \\
\hline Morton et al. (2002) (Morton MS, & 17840 \\
$\quad$ unpublished results) & 14600 \\
Pumford et al. (2002) & 10800 \\
Wiseman et al. (2002) & 12600 \\
Wiseman et al. (2002) & 11322 \\
Horn-Ross et al. (2000) & $4710 \dagger$ \\
USDA-IUS database & 10501 \\
\hline
\end{tabular}

USDA, United States Department of Agriculture; ISU, lowa State University.

*Plain soya milk; McCance \& Widdowson food code 12042; mean phyto-oestrogen content $11800 \mu \mathrm{g}$ per $100 \mathrm{~g}$.

† Iced soya milk.

$\ddagger$ United States Department of Agriculture \& Agricultural Research Service (2004).

mean age 40 (range 19-76) years and ten vegetarians, nine females, one male, mean age 36 (range $21-56$ ) years. Ethical approval was granted for the study and signed consent was obtained from each subject.

Subject weight and height were recorded at the start and end of the 1 week of weighed food recording (Bingham et al. 1988). BMI was calculated for each subject and BMR was calculated using Schofield equations (Schofield et al. 1985). Energy intake (EI) from the food diaries (using 'Microdiet'; Downlee Systems Ltd., Downlee Lodge SK23 9UB, UK) was used to calculate the EI:BMR ratio for each volunteer. EI:BMR had to be greater than or equal to 1.2 to indicate subject compliance. Dietary composition was calculated using 'Microdiet' and individual and mean group isoflavone intakes were estimated using Excel (Microsoft Corporation, Redwood, WA, USA) and SPSS (SPSS Inc., Chicago, IL, USA) statistical analysis programs.

Isoflavone intake in the vegetarian and the omnivorous groups were recorded (Table 9) and compared by Student's $t$ test. The percentage contribution for each of the major POcontaining foods to mean intake of each group, i.e. vegetarian or omnivore, was calculated and foods were listed in order of greatest dietary isoflavone contributor to lowest contributor (Table 10).

\section{Results}

A database containing isoflavone (total genistein + daidzein) concentrations in $\mu \mathrm{g}$ per $100 \mathrm{~g}$ allocated to approximately
Table 9. Mean daily dietary genistein (G) plus daidzein (D) intake for vegetarian and omnivorous groups and total volunteer group using $7 \mathrm{~d}$ diaries and newly constructed isoflavone database

\begin{tabular}{lclrr}
\hline & \multicolumn{4}{c}{ G + D intake $(\mathrm{mg} / \mathrm{d})$} \\
\cline { 2 - 5 } Vegetarian or omnivore* $^{*}$ & Mean & \multicolumn{1}{c}{ Range } & SEM & $n$ \\
\hline Vegetarian & 7.4 & $0.04-24.9$ & 3.05 & 10 \\
Omnivore & 1.2 & $0.2-3.5$ & 0.43 & 9 \\
Total & 4.5 & $0.04-24.91$ & 1.89 & 19 \\
\hline
\end{tabular}

${ }^{*}$ Vegetarian $v$. omnivore, $P=0.07$.

6000 foods was constructed and placed on the website at http://medicine.st-and.ac.uk/research/docs/ritchie/. To access the database the user name and password are gentian and violet respectively.

Where a value has been derived from a database containing genistein and daidzein values obtained by a variety of methods (such as in the United States Department of Agriculture database), the reference reflects this. Hence, if HPLC and GC-MS were used, this is represented as GC-MS/HPLC. Food reference codes are based on McCance \& Widdowson's The Composition of Foods, 4th ed. (Paul \& Southgate, 1978) and 5th ed. (Royal Society of Chemistry, 1991), together with the 1980 and 1985 supplements.

The following symbols are used:

$\mathrm{N}=$ currently no known value (from recent analysis)

$\mathrm{e}=$ estimated value (usually from a similar food where genistein + daidzein concentrations have been measured) $\mathrm{c}=$ calculated value

$\mathrm{r}=$ recipe used

$\mathrm{c} / \mathrm{r}=$ value calculated using a recipe

$\mathrm{m}=$ measured value

$\mathrm{T}=$ source of value and rationale for using it are outlined

(Ritchie, 2003)

\section{Subject compliance}

Mean subject weight $(\mathrm{kg})$ at the start and end of the recording period was 67.1 (range 46.5-117) and 67.1 (range 46.6116.0), which indicated good compliance regarding usual food intake.

Individual isoflavone intakes are represented graphically in Fig. 1.

Table 8. Estimated genistein (G) plus daidzein (D) values for foods not analysed (FN) compared with similar foods which have been analysed (FA) (Liggins et al. 1998)

\begin{tabular}{lclc}
\hline FA for $G+D$ & Measured G + D content $(\mu \mathrm{g}$ per100 g) & \multicolumn{1}{c}{ FN for G $+\mathrm{D}$} & Estimated G $+\mathrm{D}$ content $(\mu \mathrm{g}$ per100 g) \\
\hline Readybrek & 0 & Porridge with milk & 0 \\
Chickpeas, cooked & $24 \cdot 1$ & Chickpeas, tinned & $24 \cdot 1$ \\
Lentils red, split & 0.5 & Lentils, green and brown & 0.5 \\
Carrots, canned & 0 & Carrots, new, boiled & 0 \\
Broccoli, purple & 1.8 & Broccoli, green & $1 \cdot 8$ \\
Tomatoes, raw & 3.25 & Tomatoes, cherry & 3.25 \\
Peppers, green & 0 & Peppers, red & 0 \\
Fruit cocktail in syrup & 1.54 & Fruit cocktail in juice & 1.54 \\
Oranges & 0 & Grapefruit & 0 \\
\hline
\end{tabular}


Table 10. Main food sources of isoflavones (genistein (G) plus daidzein (D)) for each group and percentage contribution to daily average

\begin{tabular}{|c|c|c|c|}
\hline \multicolumn{2}{|c|}{ Vegetarians } & \multicolumn{2}{|c|}{ Omnivores } \\
\hline Food & Percentage contribution & Food & Percentage contribution \\
\hline Soya milk & 82 & Soya yogurts & $41 \cdot 2$ \\
\hline Not Bacon ${ }^{\circledR}$ & 6 & Wholemeal bread & $30 \cdot 4$ \\
\hline Soya mince & $5 \cdot 1$ & White bread & 11 \\
\hline Wholemeal bread & $2 \cdot 7$ & Wholemeal toast & $6 \cdot 9$ \\
\hline White bread & 1.9 & White toast & 3 \\
\hline White toast & 0.9 & Sultanas & 0.9 \\
\hline Wholemeal toast & 0.2 & Nan bread & 0.8 \\
\hline Croissants & 0.2 & Garlic bread & 0.7 \\
\hline Pitta bread & $0 \cdot 1$ & Muffins & 0.2 \\
\hline Biscuits & 0.09 & Brown bread & 0.1 \\
\hline Beans, green and kidney & 0.03 & Scones & 0.1 \\
\hline Raisins & 0.03 & Pitta bread & 0.1 \\
\hline Soya sauce & 0.02 & Shredded wheat & 0.1 \\
\hline
\end{tabular}

Main sources of dietary isoflavones and intake $(\mathrm{mg} / \mathrm{d})$ foreach group

The main food sources of isoflavones and subject intakes from these sources $(\mathrm{mg} / \mathrm{d}$ over the $7 \mathrm{~d}$ recording) for the vegetarian group were soya milk (plain) $(24 \cdot 5-15 \cdot 3)$, soya mince $(3 \cdot 8)$, meat-substitute foods containing textured vegetable protein and soya protein isolate (0.4), wholemeal bread and rolls $(0 \cdot 3)$, white bread and rolls $(0.4)$, bread varieties such as croissants $(0 \cdot 2)$ and pitta breads $(<0 \cdot 1)$, beans $(<0 \cdot 1)$, raisins $(<0 \cdot 1)$ and soya sauce $(<0 \cdot 01)$.

The main food sources of isoflavones and subject intakes from these sources (mg/d over the $7 \mathrm{~d}$ recording) for the omnivorous group were soya yogurts $(2 \cdot 8)$, wholemeal bread $(0 \cdot 3)$ and rolls $(0.2)$, white bread $(0.3)$ and rolls $(0.2)$, varieties of bread such as garlic bread $(0 \cdot 1)$, nan bread $(<0 \cdot 1)$ and brown bread $(0 \cdot 2)$, sultanas $(<0 \cdot 1)$ and scones $(<0 \cdot 1)$.

\section{Discussion}

Assessment of dietary intake of specific nutrients or nonnutrients tends to be based on information obtained from food diaries, dietary recall or food-frequency questionnaires, all of which have to be analysed using a database containing appropriate values for foods consumed. Although dietary intake of isoflavones is correlated with intake of soya and soya-based foods (Verkasalo et al. 2001), a number of studies report apparently low dietary isoflavone intakes in Western diets (Jones et al. 1989; Verkasalo et al. 2001) due to the lack of genistein plus daidzein values for non-soya-based foods or the restricted range of non-soya-based foods included in the dietary assessment (Kirk et al. 1999). Examples of nonsoya-based foods that contain genistein and daidzein are processed foods, bakery products and composite foods such as salads (containing raisins, rice, chickpeas, haricot beans, butter beans and beansprouts), desserts and mixed vegetable dishes.

The analysis required, of the extensive range of foods consumed in the UK, in order to create a fully comprehensive isoflavone database for use in epidemiological studies would not be feasible in terms of time and costs.

The current database was originally developed for the analysis of food-frequency questionnaires used in a study

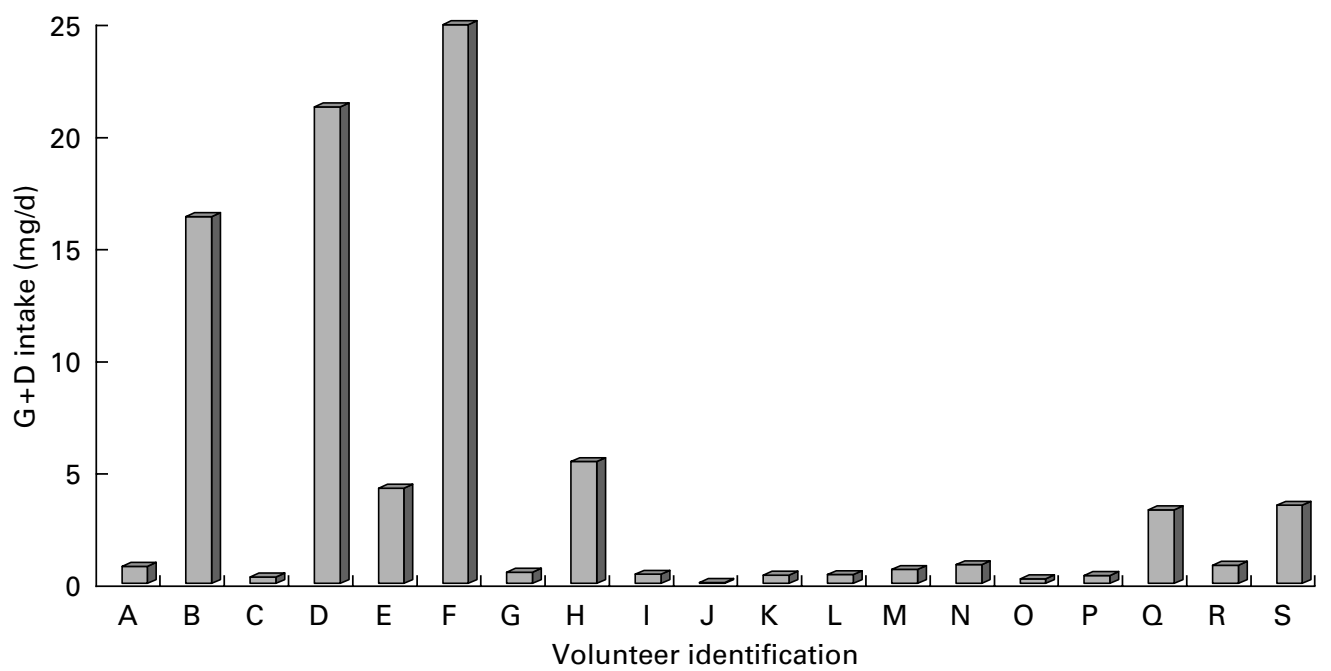

Fig. 1. Individual dietary isoflavone (genistein (G) plus daidzein (D)) intake using $7 \mathrm{~d}$ weighed food diaries and isoflavone database. Volunteers $\mathrm{A}$ to $\mathrm{J}$ were vegetarians; volunteers $\mathrm{K}$ to $\mathrm{S}$ were omnivores. 
investigating isoflavone and prostate cancer risk (Food Standards Agency project number FS2069). It was assumed that this more comprehensive database would provide more accurate information about actual isoflavone intake across a range of intakes and, in particular, in populations not consuming a soya-based diet.

Other methods for assessing total isoflavone intake per d were employed by Clarke and colleagues (Clarke et al. 2003, 2004; Clarke \& Lloyd, 2004). The researchers analysed vegetarian duplicate diets and food groups from the 1998 Total Diet Survey for isoflavones. There was considerable agreement between the two methods (isoflavone database and food group analysis) used for assessing the contribution on non-soya-based food groups to isoflavone intake. Clarke et al. (2004) report the isoflavone contribution of each food group to isoflavone intake from highest to lowest as bread, processed meat, fish products, cereals, fruit products and nuts, which is largely in agreement with the order indicated in the new database.

\section{Comparison with other databases}

The isoflavone databases produced by the United States Department of Agriculture and Iowa State University (United States Department of Agriculture \& Agricultural Research Service, 2004) and Pillow et al. (1999) contain foods eaten in America but not obtainable in the UK, for example, 'Bacon bits', 'Baco's', 'Arrowhead Mills multigrain corn bread', etc. Furthermore the isoflavone content of breads (white bread and wholegrain) in the database produced by Horn-Ross et al. (2000a) differ considerably from the values obtained by Liggins et al. (2002). This is probably because soya flour is added to bread (Liggins et al. 2002) and different countries use different amounts in their bakery products. For this reason, isoflavone values assigned by Horn-Ross et al. (2000a) to bakery products were not used in the database for foods eaten in the UK. The VENUS database contains isoflavone values for foods analysed using a variety of methods, internal standards and methods of detection. The lack of consistency in methods of analysis and restricted number of foods limit the use of this database in epidemiological studies. The advantages and strengths of the newly constructed database are due to the large number of UK foods which have been used in its construction. Many PO values are obtained from the GCMS analysis, which is both reliable and recent. In addition, many values were derived from recipe calculations relating to the extensive range of foods sampled during the database construction. Furthermore, the database includes a range of bakery products such as toast, muffins, croissants, Chelsea buns, pitta bread and nan bread, a range of salads such as bean salad, Florida salad, potato salad, and coleslaw and a range of combined dishes such as fruit pie and wholemeal pancakes stuffed with vegetables. As such it is the first comprehensive isoflavone database to be constructed for use in UK-based studies assessing isoflavone intake.

\section{Dietary intake of isoflavones}

Analysis of food diaries using the database estimated a dietary isoflavone intake of $1 \cdot 2$ (range $0 \cdot 2-3 \cdot 5$ ) $\mathrm{mg} / \mathrm{d}$ for the omnivor- ous group and a mean dietary intake for the total group of $4.45 \mathrm{mg} / \mathrm{d}$. This is higher than the value of $<1 \mathrm{mg} / \mathrm{d}$ quoted by Jones et al. (1989), as a result of HPLC analysis of diet samples obtained during the 1987 British Total Diet Survey.

Since 1989, the addition of soya products to food items in supermarkets has increased and it is probable that the Total Diet Survey underestimates the mean intake of isoflavones in the UK. Horn-Ross et al. (2000) assessed the mean isoflavone intake in 447 non-Asian women (age 50-79 years) in the San Francisco Bay area, USA, using a modified food-frequency questionnaire and a newly constructed database. Mean intakes of genistein and daidzein were estimated as 1.5 and $1.3 \mathrm{mg} / \mathrm{d}$, respectively, resulting in a total isoflavone intake of genistein plus daidzein equal to $2 \cdot 8 \mathrm{mg} / \mathrm{d}$.

This value is similar to that of $3 \mathrm{mg} / \mathrm{d}$ proposed by Clarke et al. (2003) based on analysis of samples obtained from the 1998 UK Total Diet Survey. This intake was obtained exclusively from bread and processed meats. It is also in agreement with $3.5 \mathrm{mg}$ as being the upper range of low isoflavone intakes reported in the present study. During validation of the database Ritchie et al. (2004a) indicated that, at low isoflavone intakes, the database underestimates intake by $1.2-2.2 \mathrm{mg}$. By adding this to the mean intake of $1.2 \mathrm{mg} / \mathrm{d}$, estimated using the database, isoflavone intake at low intakes (mainly due to breads) agrees with the value of $3 \mathrm{mg}$ quoted by Clarke et al. (2003).

Using the newly constructed database, a mean vegetarian isoflavone intake of $7.4 \mathrm{mg} / \mathrm{d}$ was estimated. This was expected since vegetarian diets were assumed to contain more plant-based foods and possibly more food items consisting of meat substitutes and likely to contain soya.

Mean daily intakes of $10.5 \mathrm{mg} / \mathrm{d}$ were measured in thirtyfive duplicate vegetarian diets by Clarke et al. (2003) using LC-MS. Reasons for the difference between the estimated mean isoflavone intake for the vegetarian group in the present study and the measured intake may include the small sample size in the present study. In addition, one vegetarian in the present study did not eat bread and wheat products. These foods are major sources of PO in non-Asian diets (Horn-Ross et al. 2000).

The main food sources of isoflavones for each group in the present study were soya milks and yogurts, soya and textured vegetable protein-based foods, breads, dried fruit. This is in agreement with work carried out by Horn-Ross et al. (2000b) who found that tofu, doughnuts, soya milk and bread were primary sources of PO for post-menopausal women in the USA.

The standard errors of the mean associated with estimated isoflavone intake were high (Table 9) due to the small sample size and large range of estimated intakes. However, the aim of the present study was to construct a new, more comprehensive isoflavone database and test it, both to find out the number of foods requiring isoflavone values and how the estimated intakes compared with published values. For the present study 5570 foods on the database were initially assigned an isoflavone value, of which 4887 occur as distinct foods. A total of 4852 foods are allocated a value of zero isoflavone due to estimates, measured values or isoflavone content unknown.

By adding estimated values, the final database contains 5951 foods assigned an isoflavone value. 
There is good correlation ( $r$ 0.98) between estimated isoflavone intake using the database and measured isoflavone intake from duplicate diet analysis (Ritchie et al. 2004a). Hence, results of duplicate diet analysis demonstrate the ability of the database to assess accurately dietary intakes of isoflavones.

This new database makes a valuable contribution to the requirement for a comprehensive isoflavone database available for use in epidemiological studies assessing the effect of isoflavone intake on health. As more information on the isoflavone content of foods becomes available, the database can be updated and added to. The construction of the new database and its availability, however, provides the initial step for future studies involving a more accurate assessment of dietary intakes of phytochemicals and their effects on health and disease prevention.

\section{Acknowledgements}

The Anonymous Trust, University of Dundee, supported the study.

\section{References}

Adlercreutz H \& Mazur W (1997) Phyto-oestrogens and western diseases. Ann Med 29, 95-120.

Bingham SA, Atkinson C, Liggins J, Bluck L \& Coward A (1998) Phyto-estrogens: where are we now?" Br J Nutr 79, 393-406.

Bingham SA, Nelson M, Paul AA, et al. (1988) Methods for data collection at an individual level. In Manual on Methodology for Food Consumption Studies, pp. 54-106 [ME Cameron and WA van Stavern, editors]. New York: Oxford University Press.

Clarke DB, Barnes KA, Castle L, Rose M, Wilson LA, Baxter MJ, Price KR \& DuPont MS (2003) Levels of phytoestrogens, inorganic trace-elements, natural toxicants and nitrate in vegetarian duplicate diets. Food Chem 81, 287-309.

Clarke DB, Barnes KA \& Lloyd AS (2004) Determination of unusual soya and non-soya phytoestrogen sources in beer, fish products and other foods. Food Addit Contam 21, 949-962.

Clarke DB \& Lloyd AS (2004) Dietary exposure estimates of isoflavones from the 1998 UK Total Diet Study. Food Addit Contam 21, 305-316.

Franke AA, Custer LJ, Cerna CM \& Narala K (1995) Rapid HPLC analysis of dietary phytoestrogens from legumes and from human urine. Proc Soc Exp Biol Med 208, 18-26.

Glitso L, Mazur W, Adlercreutz H, Wahala K, Makela T, Sandstrom B \& Bach Knudsen KE (2000) Intestinal metabolism of rye lignans in pigs. Br J Nutr 84, 429-437.

Heald C, Bolton-Smith C, Ritchie MR, Morton MS \& Alexander FE (2005) Phyto-oestrogen intake in Scottish men: use of serum to validate a self-administered food-frequency questionnaire. Eur $J$ Clin Nutr (In the Press).

Horn-Ross P, Barnes S, Lee M, Coward L, Mandell JE, Koo J, John EM \& Smith M (2000a) Assessing phyto-oestrogen exposure in epidemiologic studies: development of a database (United States). Cancer Causes Control 11, 289-298.

Horn-Ross P, Lee M, John E \& Koo J (2000b) Sources of phyto-oestrogen exposure among non-Asian women in California. Cancer Causes Control 11, 299-302.

Jones A, Price K \& Fenwick G (1989) Development and application of a high-performance liquid chromatographic method for the analysis of phytoestrogens. J Sci Food Agric 46, 357-364.
Kirk P, Patterson RE \& Lampe J (1999) Development of a soy food frequency questionnaire to estimate isoflavone consumption in US adults. J Am Diet Assoc 99, 558-563.

Knight DC, Eden JA, Huang JH \& Waring MA (1998) Isoflavone content of infant foods and formulas. J Paediatr Child Health 34, 135-138.

Liggins J, Bluck LJC, Coward WA \& Bingham SA (1998) Extraction and quantification of daidzein and genistein in food. Anal Biochem 264, $1-7$.

Liggins J, Bluck LJC, Runswick S, Atkinson C, Coward WA \& Bingham SA (2000) Daidzein and genistein content of fruits and nuts. J Nutr Biochem. 11, 326-331.

Liggins J, Bluck LJC, Runswick S, Atkinson C, Coward WA \& Bingham SA (2000) Daidzein and genistein contents of vegetables. Br J Nutr 84, 717-725.

Liggins J, Mulligan A, Runswick S \& Bingham SA (2002) Daidzein and genistein content of cereals. Eur J Clin Nutr 56, 961-966.

Mazur W \& Adlercreutz H (1998) Natural and anthropogenic environmental oestrogens: the scientific basis for risk assessment. Naturally occurring oestrogens in food. Pure Appl Chem 70, $1759-1776$.

Mazur W, Fotsis T, Wahala K, et al. (1996) Isotope dilution gas chromatographic-mass spectrometric method for the determination of isoflavonoids coumestrol and lignans in food samples. Anal Biochem 233, 169-180.

Mazur W, Uehara M, Wahala K \& Adlercreutz H (2000) Phyto-oestrogen content of berries, and plasma concentrations and urinary excretion of enterolactone after a single strawberry-meal in human subjects. Br J Nutr 83, 381-387.

Mazur WM, Duke JA, Wahala K, Rasku S \& Adlercreutz H (1998) Isoflavonoids and lignans in legumes: nutritional and health aspects in humans. J Nutr Biochem 9, 193-200.

Mazur WM, Wahala K, Rasku S, et al. (1998) Lignan and isoflavonoid concentrations in tea and coffee. Br J Nutr 79, 37-45.

Murphy P, Song T, Buseman G \& Barua K (1999) Isoflavones in retail and institutional soy foods. J Agric Food Chem 47, 2697-2704.

Nesbitt PD \& Thompson LU (19997) Lignans in homemade and commercial products containing flax seed. Nutr Cancer 29, 222-227.

Obermeyer WR, Musser SM, Betz JM, et al. (1995) Chemical studies of phyto-oestrogens and related compounds in dietary supplements: flax and chaparral. Proc Soc Exp Biol Med 208, 6-12.

Ovaskainen M, Valsta L \& Lauronen J (1996) The compilation of food analysis values as a database for dietary studies - the Finnish experience. Food Chem 57, 133-136.

Paul AA \& Southgate DAT (1978) McCance, Widdowson's The Composition of Foods, 4th ed. London: HM Stationery Office.

Pillow P, Duphorne C, Chang S, et al. (1999) Development of a database for assessing dietary phyto-oestrogen intake. Nutr Cancer 33, $3-19$.

Pumford SL, Morton MS, Turkes A \& Griffiths K (2002) Determination of the isoflavonoids genistein and daidzein in biological samples by gas chromatography-mass spectrometry. Anal Clin Biochem 39, 281-292.

Reinli K \& Block G (1996) Phytoestrogen content of foods - a compendium of literature values. Nutr Cancer 26, 123-148.

Ritchie MR (2003) Measurement of phyto-oestrogen content of food, plasma and urine. Derivation and validation of a biological marker for phyto-oestrogen intake. PhD Thesis, , St Andrews University.

Ritchie MR, Morton MS, Deighton N, Blake A \& Cummings JH (2004a) Plasma and urinary phytoestrogens as biomarkers of intake: validation by duplicate diet analysis. $B r J$ Nutr 91, 447-457.

Ritchie MR, Morton MS, Deighton N, et al. (2004b) Plasma and urine concentrations of isoflavones as biomarkers of phyto-oestrogen 
intake following dietary soy supplementation. $J$ Evid-Based Integr Med 1, 101-112.

Ritchie MR, Morton MS, Deighton N, et al. (2004c) Investigation of the reliability of $24 \mathrm{~h}$ urine excretion as a biomarker of phytooestrogen exposure over time and over a wide range of phytooestrogen intakes. Eur J Clin Nutr 58, 1286-1289.

Rong H, Zhao Y, Lazou K, et al. (2000) Quantitation of 8-prenylnaringenin, a novel phyto-oestrogen in hops (Humulus lupulus L), hop products, and beers, by bench top HPLC-MS using electrospray ionization. Chromtographia 51, 545-552.

Royal Society of Chemistry (1991) McCance \& Widdowson's The Composition of Foods, [B Holland, AA Welch, ID Unwin, DH Buss, AA Paul and DAT Southgate, editors]. 5th ed. London: Royal Society of Chemistry and Ministry of Agriculture, Fisheries and Food.

Schofield WN, Schofield C \& James WPT (1985) Basal metabolic rate. Human Nutr Clin Nutr 39, 1-96.

Setchell KDR, Welsh MB \& Kim CK (1987) High performance liquid chromatographic analysis of phyto-oestrogens in soy protein preparations with ultraviolet, electrochemical and thermospray mass spectrometric detection. J Chromatogr 386, 315-323.

Thompson L, Robb P, Serraino M \& Cheung F (1991) Mammalian lignan production from various foods. Nutr Cancer 14, 43-52.

United States Department of Agriculture \& Agricultural Research Service (2004) USDA-Iowa State University Database on the Isoflavone Content of Foods 1999. http://www.nal.usda.gov/fnic/ foodcomp/Data/isoflav/isoflav.html.

Vegetal Estrogens in Nutrition and Skeleton (VENUS) (2005) VENUS phyto-oestrogen database. http://www.venus-ca.org.

Verkasalo PK, Appleby PN, Allen NE, Davey G, Adlercreutz H \& Key TJ (2001) Soy intake and plasma concentrations of daidzein and gensitein: validity of dietary assessment among eighty British women (Oxford arm of the European Prospective Investigation into Cancer and Nutrition). Br J Nutr 86, 415-421.

Wang GW, Kuan SS, Francis OJ, et al. (1990) A simplified HPLC method for the determination of phyto-oestrogens in soybean and its processed products. J Agric Food Chem 38, 185-190.

Wiseman H, Casey K, Clarke DB, Barnes KA \& Bowey E (2002) Isoflavone aglycon and glucoconjugate content of high and low soy UK foods used in nutritional studies. J Agric Food Chem 50, 1404-1410.

Ziegler RG (2001) The future of phytochemical databases. Am J Clin Nutr 74, 4-5.

\section{Appendix 1. Isoflavone (genistein plus daidzein) content for bakery products}

\section{White bread, toasted; food code 11106}

Genistein plus daidzein $(G+D)$ content of white bread (WB) is $292.8 \mu \mathrm{g}$ per $100 \mathrm{~g}$.

So, $\mathrm{G}+\mathrm{D}$ content of $\mathrm{WB}$, toasted $=(\%$ protein $\mathrm{WB}$, toasted $\times 292 \cdot 8) / \%$ protein $\mathrm{WB}$

$$
=\frac{9 \cdot 3 \times 292.8}{8.4}=352.2 \mu \mathrm{g} \text { per } 100 \mathrm{~g} \text {. }
$$

\section{Brown bread, toasted; food code 11073}

$\mathrm{G}+\mathrm{D}$ content of brown bread (BB) is $524.6 \mu \mathrm{g}$ per $100 \mathrm{~g}$.

So, $\mathrm{G}+\mathrm{D}$ content of $\mathrm{BB}$, toasted $=(\%$ protein $\mathrm{BB}$, toasted $\times 524.6) / \%$ protein $\mathrm{BB}$

$$
=\frac{10.4 \times 524.6}{8.5}=641.9 \mu \mathrm{g} \text { per } 100 \mathrm{~g} \text {. }
$$

Wholemeal bread, toasted; food code 11117

$\mathrm{G}+\mathrm{D}$ content of wholemeal bread (WHB) is $829.8 \mu \mathrm{g}$ per $100 \mathrm{~g}$.

So, $\mathrm{G}+\mathrm{D}$ content of $\mathrm{WHB}$, toasted $=(\%$ protein $\mathrm{WHB}$, toasted $\times 829.8) / \%$ protein $\mathrm{WHB}$

$$
=\frac{10 \cdot 8 \times 829 \cdot 8}{9 \cdot 2}=974 \cdot 1 \mu \mathrm{g} \text { per } 100 \mathrm{~g} \text {. }
$$

White rolls, crusty; food code 11123

$\mathrm{G}+\mathrm{D}$ content of white rolls, crusty (WRC) is $292.8 \mu \mathrm{g}$ per $100 \mathrm{~g}$ (assume same as WB).

So, $\mathrm{G}+\mathrm{D}$ content of $\mathrm{WRC}=(\%$ protein $\mathrm{WRC} \times 292.8) / \%$ protein $\mathrm{WB}$

$$
=\frac{9 \cdot 3 \times 292.8}{8.4}=379.9 \mu \mathrm{g} \text { per } 100 \mathrm{~g} .
$$

Protein contents are from the 5th edition of McCance and Widdowson's The Composition of Foods (Royal Society of Chemistry, 1991).

Table 4 contains genistein and daidzein values for other bakery products.

\section{Isoflavone (genistein plus daidzein) values for meat products}

\section{Pork sausages (brand name); food code 19091}

Pork and beef sausages 'Economy' contain $0.85 \%$ soya concentrate.

Assume that the $G+D$ content of soya concentrate is the $\mathrm{G}+\mathrm{D}$ content of textured vegetable protein (TVP).

$\mathrm{G}+\mathrm{D}$ content of TVP $=(68600+68000) / 2=68300 \mu \mathrm{g}$ per $100 \mathrm{~g}$.

In $100 \mathrm{~g}$ sausages, weight of TVP $=0.85 \mathrm{~g}$.

$\mathrm{G}+\mathrm{D}$ content of $100 \mathrm{~g}$ TVP $=68300 \mu \mathrm{g}$.

So, in $0.85 \mathrm{~g}$ of TVP we have $0.85 / 100 \times 68300 \mu \mathrm{g} \mathrm{G}+\mathrm{D}$. $\mathrm{G}+\mathrm{D}$ content of $100 \mathrm{~g}$ sausages $=580 \mu \mathrm{g}$ per $100 \mathrm{~g}$.

The same formula was used for beef sausages 'Premium', beef olives, beefburgers, bridie or scotch pie, and Lorne sausage. The foods and associated $\mathrm{G}+\mathrm{D}$ values are listed in Table 5 .

\section{Isoflavone (genistein plus daidzein) values for fish products}

Recipe for fish pie; McCance \& Widdowson food code 16294

$200 \mathrm{~g}$ cooked cod

$150 \mathrm{ml} \mathrm{milk}$

$400 \mathrm{~g}$ mashed potato

$15 \mathrm{~g}$ margarine

level teaspoon salt

$15 \mathrm{~g}$ flour

Total weight of ingredients $780 \mathrm{~g}$.

Only ingredient with $\mathrm{G}+\mathrm{D}$ (measured) is potatoes $(400 \mathrm{~g})$.

Content of potato in fish pie $(\%)=400 / 780=51 \cdot 28 \%$.

$\mathrm{G}+\mathrm{D}$ content of potato (old and new) $=(0 \cdot 74+3 \cdot 75) / 2$

$=2.6 \mu \mathrm{g}$ per $100 \mathrm{~g}$. 
$\mathrm{G}+\mathrm{D}$ content for total fish pie $=(2.6 \times 51.28) / 100 \mu \mathrm{g}$ per $100 \mathrm{~g}$

\section{$=1.3 \mu \mathrm{g}$ per $100 \mathrm{~g}$.}

Assume $10 \cdot 1 \%$ weight loss on cooking and $G+D$ content rises by similar amount, then the $G+D$ content of fish pie $=1.3+(10.1 \times 1.3)=(1.3+0.13) \mu \mathrm{g}$ per $100 \mathrm{~g}=1.5 \mu \mathrm{g}$ per $100 \mathrm{~g}$.

The same mathematical formula was used to calculate the $\mathrm{G}+\mathrm{D}$ content of other fish products such as fishcakes (see Table 5).

\section{Isoflavone (genistein plus daidzein) values for retail products}

Recipe for carrot and nut salad with French dressing; food code 15288 (Tesco)

$42 \mathrm{~g}$ carrot

$35 \mathrm{~g}$ French dressing

$15 \mathrm{~g}$ groundnuts

$8 \mathrm{~g}$ sultanas

Total weight $100 \mathrm{~g}$.

Groundnut content $(\%)=15 ; \mathrm{G}+\mathrm{D}$ content of groundnuts is $20.9 \mu \mathrm{g}$ per $100 \mathrm{~g}$.

Sultanas content $(\%)=8 ; \mathrm{G}+\mathrm{D}$ content of sultanas is $204 \cdot 1 \mu \mathrm{g}$ per $100 \mathrm{~g}$.
So, in $100 \mathrm{~g}$ salad $\mathrm{G}+\mathrm{D}$ content $=((15 \times 20 \cdot 9) / 100+$ $(8 \times 204 \cdot 1) / 100) \mu \mathrm{g} \mathrm{G}+\mathrm{D}$

$=(3 \cdot 1+16 \cdot 3) \mu \mathrm{g} \mathrm{G}+\mathrm{D}$

Phyto-oestrogen content of carrot and nut salad $=19.4 \mu \mathrm{g}$ per $100 \mathrm{~g}$.

\section{Appendix 2. Genistein plus daidzein content of Streaky Strips ${ }^{\circledR}$}

Streaky Strips ${ }^{\circledR}$, food code MR11, contain $43 \%$ textured vegetable protein (TVP; wheat gluten and soya protein concentrate), soya and maize protein, and soya protein isolate (SPI; assume $14 \%$ )

We can make the following assumptions:

$50 \%$ TVP is wheat protein and $50 \%$ is soya protein;

Genistein plus daidzein $(\mathrm{G}+\mathrm{D})$ content is $50 \% \mathrm{G}+\mathrm{D}$ content of soya flour (Riaz, 'Soya and Health 2000').

$100 \mathrm{~g}$ Streaky Strips ${ }^{\circledR}$ contains $23 \mathrm{~g}$ TVP and $14 \mathrm{~g}$ SPI.

$\mathrm{G}+\mathrm{D}$ content of TVP $=68600 \mu \mathrm{g}$ per $100 \mathrm{~g}$.

$\mathrm{G}+\mathrm{D}$ content of SPI $=105000 \mu \mathrm{g}$ per $100 \mathrm{~g}$.

So, total G $+\mathrm{D} \quad$ content $=((23 \times 68600)+14 \times$ 105000))/100

Phyto-oestrogen content of Streaky Strips ${ }^{\circledR}=(15778+$ 14700) $\mu \mathrm{g}$ per $100 \mathrm{~g}=30478 \mu \mathrm{g}$ per $100 \mathrm{~g}$. 